\title{
Genetic Improvement and Diversity in Snake River Wheatgrass (Elymus wawawaiensis) (Poaceae: Triticeae)
}

\author{
Kevin B. Jensen, ${ }^{1}$ Ivan W. Mott, ${ }^{1}$ Joseph G. Robins, ${ }^{1}$ Blair L. Waldron, ${ }^{1}$ and Mark Nelson ${ }^{2}$ \\ Authors are ${ }^{1}$ Research geneticists, US Department of Agriculture-Agricultural Research Service, Forage and Range Research Laboratory, Utah State \\ University, Logan, UT 84322, USA; and ${ }^{2}$ Beaver County Extension Agent, Utah State University, Beaver, UT 84713, USA.
}

\begin{abstract}
With the increased emphasis on using native plant materials in range revegetation programs in the western United States it is critical to identify genetically similar groups and develop native grasses that are competitive with invasive weeds, easy to establish, and persistent, and that produce high seed yield. A grass that shows appreciable drought tolerance on arid rangelands is Snake River wheatgrass (Elymus wawawaiensis J. Carlson \& Barkworth). This study was designed to estimate genetic relationships and underlying genetic components for seed and forage trait improvement between plant introductions (PIs) of Snake River wheatgrass, 28 half-sib Snake River wheatgrass families (HSFs), and cultivars Secar and Discovery at Nephi, Utah, between 2005 and 2006. Based on molecular genetic diversity data in Snake River wheatgrass, with the exception of the PIs originating from Enterprise, Oregon, all other collections and cultivars are not genetically different and represent a common gene pool from which to develop improved Snake River wheatgrass germplasm. Selection in Snake River wheatgrass for total seed yield $\left(\mathrm{g} \cdot\right.$ plot $\left.^{-1}\right), 100$-seed weight $(\mathrm{g})$, and seedling emergence from a deep planting depth had a positive effect. Further increases through selection and genetic introgression from hybridization with PIs will likely increase seed yield and 100-seed weight, but will not increase seedling emergence. Increases in dry matter yield (DMY) were observed after two cycles of selection in the HSFs compared to the PIs. There remains considerable genetic and phenotypic variation to further increase DMY in Snake River wheatgrass through selection and hybridization. Trends in forage nutritional quality were not observed after two cycles of selection in the HSFs or the PIs and will not likely result in improvement. Through recurrent selection, populations of Snake River wheatgrass have been and can be developed to more effectively establish and compete on annual weed-infested rangelands.
\end{abstract}

\begin{abstract}
Resumen
Con el aumento en el interés de usar plantas nativas para los programas de revegetación en el oeste de los Estados Unidos es necesario identificar grupos genéticamente similares y desarrollar pastos nativos que sean competitivos con plantas invasoras, fácil de establecerse, persistentes y con alto rendimiento en producción de semilla. El pasto que muestra buena tolerancia a la sequia en pastizales áridos es el Snake River wheatgrass (Elymus wawawaiensis J. Carlson \& Barkworth). Este estudio fue diseñado para estimar la relación genética y subrayar los componentes genéticos para el rasgo de mejoramiento de la semilla y el forraje entre introducción de plantas (PIs) de Snake River wheatgrass, 28 medio hermanas familias de Snake River wheatgrass (HSFs) y de cultivos de Secar y Discovery en Nephi, Utah, entre los años 2005 y 2006. Basados en datos de diversidad genética molecular del pasto Snake River wheatgrass con excepción del PIs originario de Enterprise, Oregon, todas las demás colecciones y cultivos no son genéticamente diferentes y representan un grupo con un gen común del cual se desarrollo el germoplasma mejorado del Snake River wheatgrass. La selección del Snake River wheatgrass por rendimiento total de semilla $\left(\mathrm{g} \cdot \mathrm{parecela}^{-1}\right.$ ), peso de semilla $(\mathrm{g})$ y emergencia de plántulas de una profundidad de plantación profunda tuvo efecto positivo. Aunado al incremento a través de selección y introgresion genética de hibridación con PIs podría incrementar el rendimiento de semilla y el peso de 100 semillas pero no aumentar la emergencia de plántulas. El incremento en rendimiento de materia seca (RMS) fue observado después de 2 ciclos de selección en el HSFs comparado con el PIs. Ahí queda considerable variación genética y fenotípica para futuro incremento en rendimiento de materia seca (RMS) en Snake River wheatgrass a través de selección e hibridación. Tendencias en la calidad nutricional del forraje no se observaron después de 2 ciclos de selección en el HSFs ni en el PIs y no es probable que resulte en mejoramiento. A través de selección recurrente de poblaciones de Snake River wheatgrass han sido y pueden ser desarrolladas para establecerse con mayor efectividad y competir con hierbas anuales en pastizales infestados.
\end{abstract}

Key Words: forage quality, genetic diversity, germplasm improvement, seedling establishment

\section{INTRODUCTION}

Correspondence: Kevin B. Jensen, US Dept of Agriculture-Agricultural Research Service, Forage and Range Research Laboratory, Utah State University, Logan, UT 84322-6300, USA. Email: kevin.jensen@ars.usda.gov

Manuscript received 10 October 2010; manuscript accepted 13 August 2011.
Vast areas of semiarid rangelands in the western United States are severely disturbed, frequently burned, increasingly eroded, and subsequently infested with troublesome weeds such as cheatgrass (Bromus tectorum L.), medusahead rye (Taeniatherum asperum [L.] Nevski), and others. Reseeding these 
disturbed rangelands with genetically improved plant materials that are competitive enough during the establishment growth phase to replace existing undesirable vegetation is often the most plausible and economically feasible way to reclaim such sites (Asay et al. 2003). With the increased emphasis on using native (locally collected) plant materials in range revegetation programs in the western United States (Bureau of Land Management 1999, 2000), it is critical to identify genetically similar groups and develop native grasses if needed within these groups that are competitive with invasive weeds, easy to establish, and persistent, with increased seed yield. Failure to develop improved native grasses will result in increased fire frequency, loss of soil structure, increased soil erosion, and economically unproductive rangelands (Norton et al. 2004; Young and Clements 2009).

Little effort has focused on native grass breeding, selection, and cultivar development (Asay et al. 2001a). Much of the past native plant improvement has centered on locally collected ecotypes that have resulted in limited success in rangeland revegetation. Additionally, commercially available seed of most native species is limited and does not meet current market demands and can be costly. In recent studies on six range sites, native grasses were more difficult to establish, less productive and persistent, and less defoliation-tolerant under severe water stress than their introduced counterparts (Asay et al. 2001a).

Snake River wheatgrass (Elymus wawawaiensis J. Carlson \& Barkworth) is a native bunchgrass with significant drought tolerance (Jones and Nielson 1997) and grows primarily in shallow, rocky soils on slopes of the Salmon, Snake, and Yakima rivers of Washington, northern Oregon, and Idaho. In the Palouse region of Washington, Snake River wheatgrass is often sympatric with bluebunch (Pseudoroegneria spicata [Push.] Á. Löve); however, it tends to be more drought-tolerant and inhabits more shallow, rocky soils compared to mediumto fine-textured loess soil frequently inhabited by bluebunch (Barkworth et al. 2007). Snake River wheatgrass is included in many of the rangeland restoration seed mixes on disturbed rangelands. However, it continues to exhibit reduced seedling establishment and persistence under extremely harsh dry environments (Asay et al. 2001a).

Prior to 1986, Snake River wheatgrass was treated taxonomically as bluebunch wheatgrass. However, genetic relationships described by Carlson and Barkworth (1997) demonstrated that Snake River wheatgrass is more closely related to thickspike wheatgrass (Elymus lanceolatus [Scribn. \& J.G. Sm.] Gould) in that they are allotetraploids $(2 n=28 ; S t S t H H)$ comprising the St genome originating from the genus Pseudoroegneria and the $\mathrm{H}$ genome from the genus Hordeum. Snake River wheatgrass differs genomically from bluebunch wheatgrass in that bluebunch comprises exclusively the $S t$ genome and has two ploidy levels, diploid $(2 n=14 ; S t S t)$ and autotetraploid $(2 n=28$; StStStSt).

Snake River wheatgrass exhibits a greater degree of spikelet imbrication, a more lanceolate glume shape, and greater seedling pubescence than bluebunch wheatgrass. Snake River wheatgrass lacks the presence of serrate barbs on seedling leaf margins found on bluebunch wheatgrass seedlings (Jones et al. 1991). Snake River wheatgrass is awned compared to the awnless character in thickspike wheatgrass.
Commercially available material of Snake River wheatgrass is restricted to the cultivars Secar and Discovery. The cultivar Secar was originally released as a bluebunch wheatgrass in 1980 (Morrison and Kelly 1981) and originated from a single collection near Lewiston, Idaho. Secar is adapted to regions receiving $20 \mathrm{~cm}$-plus rainfall at lower elevations of the Pacific Northwest. Since the release of Secar in 1980, it has since been reclassified as Snake River wheatgrass based on its genomic structure (Carlson and Barkworth 1997). It is an early maturing bunchgrass with relatively good seedling establishment under drought conditions. Asay et al. (2001a) reported that Secar Snake River wheatgrass established and persisted as well as or better than all other native and introduced grasses evaluated under drought conditions at Yakima, Washington. In general, plantings of Secar have been successfully established on sites that receive as little as $20 \mathrm{~cm}$ annual precipitation. Moreover, regrowth after defoliation of Secar is greater compared to that of bluebunch wheatgrass (Jones and Nielson 1997), but less than crested wheatgrass (Agropyron desertorum [Fischer ex Link] Schultes; Asay et al. 2001a). The cultivar Discovery was released in 2008 and is a multiple-origin release originating from 15 Snake River wheatgrass collections with increased seedling establishment over Secar (Jones 2008).

Given the narrow geographical distribution of Snake River wheatgrass, there is a need to describe the genetic relationship that exists between plant introductions (PIs), half-sib families (HSFs), and cultivars. Based on the genetic relationships, can Snake River wheatgrass HSFs be generated that are genetically similar to the overall species structure, but exhibit improved seed characteristics, seedling establishment, dry matter production (DMY), and forage nutritional quality? Is there sufficient genetic variation within PIs and HSFs of Snake River wheatgrass to continue to improve populations for the above traits though selection and hybridization?

\section{METHODS}

\section{Plant Materials}

Forty-five PIs of Snake River wheatgrass were obtained in 2003 from the National Plant Germplasm System (NPGS) at Pullman, Washington (Table 1). The collection origin of each PI accession can be found on the National Genetic Resources Program database. ${ }^{1}$ Twenty-eight HSFs were obtained from a cycle-2 breeding population of Snake River wheatgrass with parental material originating from the cultivar Secar, PI610979 from Yakima, Washington, and PI537314 from Roosevelt, Washington. This population underwent two cycles $\left(\mathrm{C}_{2}\right)$ of phenotypic recurrent selection for forage yield, seed yield, and seedling establishment. For evaluation of seedling establishment, an eight-clone synthetic (Syn-1) was developed from the $\mathrm{C}_{2}$ population by evenly bulking seed from the HSF that had the highest total seed weight.

\section{Field Plot Design}

Field plots were located $121 \mathrm{~km}$ south of Salt Lake City, Utah, at the Nephi Dryland Research Farm (Juab County, Utah; lat $39^{\circ} 71^{\prime} \mathrm{N}$, long $111^{\circ} 83^{\prime} \mathrm{W} ; 1615$ m elevations; soil type: Nephi

${ }^{1}$ www.ars-grin.gov 
Table 1. A list of plant introductions (PIs) and their means for dry matter yield (DMY), crude protein (CP), in vitro true digestibility (IVTD), neutral detergent fiber (NDF), digestible NDF (dNDF), total seed weight, 100-seed weight, and seedling emergence.

\begin{tabular}{|c|c|c|c|c|c|c|c|c|}
\hline Accession (PI) & $\operatorname{DMY}\left(g \cdot \operatorname{plot}^{-1}\right)$ & $\mathrm{CP}\left(\mathrm{g} \cdot \mathrm{kg}^{-1}\right)$ & $\operatorname{IVTD}\left(\mathrm{g} \cdot \mathrm{kg}^{-1}\right)$ & $\operatorname{NDF}\left(\mathrm{g} \cdot \mathrm{kg}^{-1}\right)$ & $\operatorname{dNDF}\left(\mathrm{g} \cdot \mathrm{kg}^{-1}\right)$ & $\begin{array}{l}\text { Total seed } \\
\text { weight }(\mathrm{g})\end{array}$ & $\begin{array}{l}100 \text {-seed } \\
\text { weight }(\mathrm{g})\end{array}$ & $\begin{array}{c}\text { Rate of seedling } \\
\text { emergence }\end{array}$ \\
\hline 16744 & 250.0 & 11.7 & 73.9 & 60.0 & 56.7 & 18.7 & 0.3 & 1.6 \\
\hline 285272 & 290.0 & 8.5 & 72.1 & 60.5 & 54.0 & 15.9 & 0.3 & 2.1 \\
\hline 285273 & 250.0 & 8.7 & 72.0 & 60.3 & 53.7 & 20.1 & 0.4 & 2.8 \\
\hline Secar & 246.0 & 9.6 & 71.0 & 61.4 & 52.8 & 19.2 & 0.3 & 1.5 \\
\hline 506261 & 243.0 & 10.5 & 72.6 & 61.3 & 55.4 & 19.0 & 0.3 & 2.0 \\
\hline 506262 & 227.0 & 9.5 & 72.6 & 60.8 & 55.0 & 21.1 & 0.3 & 1.9 \\
\hline 506263 & 211.0 & 10.9 & 75.4 & 56.1 & 56.2 & 13.6 & 0.3 & 1.9 \\
\hline 506265 & 258.0 & 10.4 & 73.5 & 59.2 & 55.4 & 21.4 & 0.3 & 2.0 \\
\hline 506266 & 274.0 & 10.1 & 72.2 & 61.4 & 54.7 & 28.9 & 0.3 & 2.3 \\
\hline 506267 & 252.0 & 9.0 & 71.4 & 62.0 & 54.0 & 30.5 & 0.3 & 2.0 \\
\hline 506268 & 168.0 & 10.8 & 73.0 & 61.6 & 56.3 & 16.6 & 0.3 & 1.9 \\
\hline 506269 & 219.0 & 10.8 & 73.0 & 60.0 & 55.1 & 19.4 & 0.3 & 1.6 \\
\hline 506270 & 161.0 & 10.3 & 73.6 & 58.7 & 55.1 & 12.3 & 0.3 & 1.9 \\
\hline 506272 & 243.0 & 10.1 & 71.9 & 62.7 & 55.3 & 16.8 & 0.3 & 2.2 \\
\hline 506275 & 251.0 & 10.6 & 74.2 & 60.1 & 57.1 & 26.9 & 0.3 & 2.0 \\
\hline 506277 & 218.0 & 11.0 & 74.3 & 59.6 & 57.0 & 17.6 & 0.3 & 2.1 \\
\hline 506282 & 205.0 & 9.9 & 73.2 & 59.6 & 55.2 & 19.5 & 0.3 & 2.3 \\
\hline 506283 & 281.0 & 10.3 & 73.4 & 59.3 & 55.2 & 18.8 & 0.3 & 1.5 \\
\hline 506284 & 261.0 & 10.3 & 72.8 & 60.8 & 55.3 & 18.1 & 0.3 & 1.9 \\
\hline 516188 & 236.0 & 10.6 & 73.4 & 58.1 & 56.6 & 22.3 & 0.3 & 2.5 \\
\hline 516189 & 213.0 & 10.5 & 76.1 & 57.5 & 58.4 & 22.9 & 0.3 & 2.2 \\
\hline 531626 & 225.0 & 10.7 & 73.4 & 59.5 & 55.4 & 20.8 & 0.3 & 1.4 \\
\hline 531627 & 200.0 & 9.6 & 73.5 & 58.3 & 54.5 & 19.2 & 0.3 & 2.0 \\
\hline 531628 & 190.0 & 9.9 & 72.1 & 61.7 & 54.7 & 14.3 & 0.3 & 1.0 \\
\hline 531629 & 252.0 & 10.3 & 73.4 & 60.1 & 55.7 & 26.0 & 0.3 & 1.8 \\
\hline 531630 & 209.0 & 10.1 & 74.6 & 60.1 & 57.8 & 16.6 & 0.4 & 2.1 \\
\hline 537312 & 184.0 & 11.4 & 74.4 & 59.3 & 57.0 & 16.9 & 0.3 & 1.4 \\
\hline 537313 & 176.0 & 10.2 & 74.2 & 58.3 & 55.8 & 21.2 & 0.3 & 1.4 \\
\hline 537314 & 192.0 & 11.5 & 73.3 & 60.5 & 55.9 & 17.4 & 0.3 & 1.7 \\
\hline 537315 & 203.0 & 11.1 & 73.8 & 59.7 & 56.2 & 19.0 & 0.3 & 1.6 \\
\hline 537373 & 252.0 & 9.9 & 72.9 & 59.7 & 54.6 & 18.1 & 0.3 & 1.8 \\
\hline 563857 & 188.0 & 11.9 & 74.5 & 58.8 & 56.7 & 13.5 & 0.3 & 1.9 \\
\hline 563859 & 258.0 & 9.0 & 73.1 & 60.5 & 55.5 & 14.9 & 0.3 & 1.6 \\
\hline 563860 & 236.0 & 10.5 & 73.2 & 60.7 & 55.9 & 18.6 & 0.3 & 2.0 \\
\hline 563861 & 192.0 & 11.0 & 73.3 & 60.5 & 56.0 & 20.1 & 0.3 & 2.1 \\
\hline 595187 & 217.0 & 9.9 & 71.7 & 61.8 & 54.2 & 17.9 & 0.3 & 1.1 \\
\hline 595188 & 208.0 & 11.2 & 74.8 & 59.6 & 55.4 & 16.5 & 0.3 & 1.6 \\
\hline 595189 & 202.0 & 12.4 & 74.4 & 58.0 & 56.0 & 14.9 & 0.3 & 2.6 \\
\hline 595190 & 240.0 & 11.4 & 74.3 & 59.9 & 57.1 & 15.4 & 0.3 & 2.0 \\
\hline 598812 & 225.0 & 12.3 & 74.8 & 58.3 & 56.9 & 21.3 & 0.3 & 1.4 \\
\hline 598813 & 187.0 & 12.9 & 77.3 & 56.1 & 59.7 & 18.8 & 0.3 & 2.5 \\
\hline 610979 & 242.0 & 10.3 & 73.6 & 59.3 & 55.5 & 15.3 & 0.3 & 1.9 \\
\hline 610980 & 197.0 & 10.0 & 72.0 & 61.6 & 54.6 & 15.2 & 0.3 & 2.5 \\
\hline 610982 & 210.0 & 9.9 & 73.6 & 56.8 & 53.7 & 27.8 & 0.3 & 1.6 \\
\hline 610983 & 207.0 & 11.1 & 74.1 & 58.8 & 55.8 & 11.5 & 0.3 & 1.9 \\
\hline 610984 & 221.0 & 11.6 & 75.0 & 57.9 & 56.9 & 22.6 & 0.3 & 1.6 \\
\hline $\operatorname{LSD}_{(0.05)}$ & 41.7 & 1.5 & 1.7 & 1.9 & 1.8 & 7.9 & 0.01 & 0.7 \\
\hline
\end{tabular}

silt loam). Total precipitation received from 1 January through 31 December was 483 and $401 \mathrm{~mm}$ for 2005 and 2006, respectively, with about one-third occurring between March and May. Mean minimum and maximum temperatures were $2^{\circ} \mathrm{C}$ and $17^{\circ} \mathrm{C}$ and $1{ }^{\circ} \mathrm{C}$ and $17^{\circ} \mathrm{C}$ for 2005 and 2006 , respectively. Seedlings from the PIs, HSFs, and Secar were established in the greenhouse prior to transplanting in the field in April 2004. Each field plot $(1 \mathrm{~m} \times 6 \mathrm{~m})$ consisted of six plants, planted on $1-\mathrm{m}$ row centers and with $0.5 \mathrm{~m}$ plant spacing within rows. The field plot design was a randomized 
complete block with six replicates; treatments (entries) were the PIs, HSFs, and Secar.

\section{Genetic Diversity Analysis}

Fifty-five entries were analyzed for genetic diversity using amplified fragment length polymorphism (AFLP) analysis. The entries included the bluebunch wheatgrass cultivar Anatone, four cultivars of thickspike wheatgrass (Bannock, Critana, Sodar, Schwendimar), selection from the cultivar Sodar (EL-1) and an interspecific hybrid between cultivars Bannock and Secar (EW-1), Snake River wheatgrass cultivars Secar and Discovery as reference species, 45 Snake River PIs, and the Syn-1 population, which represents the HSF. Eight plants from each PI and reference species were analyzed. Fresh tissue was collected from plants growing in containers in a greenhouse at Logan, Utah. DNA was extracted using DNeasy 96-well extraction kit (Qiagen, Valencia, CA). Quantity and quality of DNA were assessed by spectrophotometry and agarose gel electrophoresis. The AFLP procedure followed the protocol of Vos et al. (1995), using the selective primers E.AAT/M.CCA, E.AGG/M.CAT, E.AGG/M.CAT, and E.ATA/M.CGG. Amplicons were separated on a capillary ABI 3730 instrument with the GS-500 LIZ size standard and GeneScan software (Applied Biosystems, Foster City, CA). Individual profiles were visualized and scored for the presence $(1)$ or absence $(0)$ of fragments with Genographer software (Version 1.6.1., Montana State University, Bozeman, MT, USA). Plants with poor amplification profiles for one or more primer pairs were removed from the study. The four selective primer pairs provided 641 bands for analysis. Raw binary data were converted to Euclidean distance with the resulting distance matrix constituting the input file for analysis of molecular variance (AMOVA) using Arlequin 2.0 software (Schneider et al. 2000). The average number of total pairwise differences among and within accessions, resulting from the AMOVA procedure, comprised the input matrix for the assembly of a neighbor-joining $(\mathrm{NJ})$ cladogram using PAUP* version 4.0b (Swofford 2002). The NJ cladogram was modified to include bootstrap confidence levels recovered from the $50 \%$ majority rule consensus of $1000 \mathrm{NJ}$ searches for the 402 individual genotyped by PAUP* version 4.0b (Swofford 2002).

\section{Seed Characteristics}

Seed production data were obtained from harvesting openpollinated seed from the last three plants in each plot on 19 July 2005 and 29 June 2006, air-drying the seed to approximately $8 \%$ seed moisture content, weighing the seed from each plot, and converting the seed weights to a per plot basis $\left(\mathrm{g} \cdot \mathrm{plot}^{-1}\right)$. Hundred-seed weight was determined by counting out four replications and averaging the weights for each year. Seedling establishment was assessed in the greenhouse the winter following seed harvest and was based on the ability of the seedling to emerge from a 7.6- $\mathrm{cm}$ seeding depth (Asay and Johnson 1980) and measured by the rate of emergence (Maguire 1962).

\section{Forage Characteristics}

Following establishment in 2004, determinations of DMY $\left(\mathrm{g} \cdot \mathrm{plot}^{-1}\right)$ were based on a plot mean basis by hand-harvesting the first three plants of each plot at postanthesis (Moore et al. 1991) to a height of about $7 \mathrm{~cm}$ on 13 June 2005 and 2 June 2006. The contents of the entire plot were oven-dried at $60^{\circ} \mathrm{C}$ in a forced-air oven to a constant weight for DMY determination. The samples were then ground in a Wiley mill and subsequently in a Cyclone mill to pass through a $1-\mathrm{mm}$ screen. Ground plant samples were scanned with a near-infrared reflectance spectroscopy (NIRS) instrument (Model 6500; Pacific Scientific Instruments, Silver Spring, MD) to estimate crude protein (CP), in vitro true digestibility (IVTD), digestible neutral detergent fiber (dNDF), and neutral detergent fiber (NDF). Representative samples were selected from each year and used as a validation data set for actual chemical analyses. This data set consisted of 88 samples each for CP, NDF, and IVTD, which were not part of the NIRS grass equation. The $R^{2}$ value for validation of CP was 0.88 (standard error of the prediction $[\mathrm{SEP}]=0.49$ ) combined across years. Corresponding $R^{2}$ values were $0.72(\mathrm{SEP}=1.27)$ for $\mathrm{NDF}$ and 0.63 $(\mathrm{SEP}=2.48)$ for IVTD.

Samples used for calibration were analyzed for nitrogen $(\mathrm{N})$ using a LECO CHN-2000 Series elemental analyzer (LECO Corp., St. Joseph, MO). Levels of CP were determined by multiplying $\mathrm{N} \times 6.25$. NDF and IVTD values were determined using procedures described by Goering and Van Soest (1970). Analysis for NDF was made with an ANKOM-200 fiber analyzer (ANKOM Technology Corp., Fairport, NY). The first stage of the IVTD procedure consisted of a 48 -h in vitro fermentation in the ANKOM Daisy II incubator (ANKOM Technology Corp.). The residual dry matter was then exposed to a standard NDF procedure. NDF digestibility values were then calculated using the initial concentrations of NDF and IVTD as a percentage of NDF (Hoffman et al. 2001).

\section{Data Analysis}

Using the MIXED (Littell et al. 1996) and IML procedures of SAS (SAS Institute, Inc. 2006), variance components, narrowsense heritabilities, and standard errors were calculated (check cultivars and PI accessions were removed for the analysis; Holland et al. 2003) based on a split-plot-in-time model. The model used was appropriate for the analysis of genetic variation and heritability in a set of HSFs (Nguyen and Sleper 1983) based on entry means across replications and was as follows:

$$
h^{2}=\sigma_{\mathrm{HSF}}^{2} /\left(\sigma_{\mathrm{HSF}}^{2}+\sigma_{\mathrm{HSFY} / y}^{2}+\sigma_{\mathrm{HSFR} / r}^{2}+\sigma_{e / y r}^{2}\right)
$$

where $\sigma_{\text {HSF }}^{2}$ is variation among HSFs, $\sigma_{\text {HSFY is variation due }}^{2}$ to the HSF by year interaction, $\sigma^{2}$ HSFR is variation due to HSF by replication interaction, $\sigma_{e}^{2}$ is residual variation, and $y$ and $r$ are the number of years and replications, respectively.

To compare the performance of the HSF with those of the check cultivars and PI accessions, a split-plot-in-time design was used employing a general linear model (SAS Institute, Inc. 2006) using plot means. Single degree of freedom contrasts tested the overall mean for the PI accessions with the check cultivars and HSF means for forage yield, quality, and seed characteristics. For the combined analysis, entry $\times$ block was used as the error term to test entry effects, and year effects were tested with year $\times$ block interaction. A Protected LSD test was 
used to separate entry means within and across years. Intercharacter correlations were calculated on entry $\times$ replication means using PROC CORR in SAS (SAS Institute, Inc. 2006).

\section{RESULTS}

\section{Molecular Genetic Diversity}

The AMOVA of AFLP variation indicates that $27 \%$ of the total variation was between accessions and $73 \%$ was within accessions, which is similar to that found in other out-crossing grasses (Jensen et al. 2009a,b). With the exception of PI 506269 and PI 506270, all Snake River wheatgrass PIs, Syn-1, and cultivars examined grouped together, sharing a similar genetic structure (Fig. 1). Based on the placement of PIs 506269 and 506270 in relation to Snake River and thickspike wheatgrass on the tree (Fig. 1), one could hypothesize that genetic introgression through hybridization has occurred between these species. Based on chromosome pairing and morphology in Elymus albicans (Scribner \& Smith) Á. Löve and Elymus albicans var. griffithsii (Scribner \& Smith) A.A. Beetle, Dewey (1970) determined their origin to be natural hybrids between Snake River and thickspike wheatgrass. Observed genetic similarity among the Snake River wheatgrass PIs, Syn-1, and cultivars suggests a close overall relationship with perhaps a small exception of PIs 516189, 51688, and 598812, which originated from Enterprise, Oregon (Fig. 1). In general, the data suggest that genetic improvement within Snake River wheatgrass as evidenced by the random placement of Secar, Discovery, and Syn-1 on the tree (Fig. 1) has not changed the overall genetic similarity within the species.

\section{Seed Characteristics}

Seed yield data were combined across years due to a nonsignificant entry by year interaction (Table 2). In the analysis across years, mean total seed yield was significantly greater in the HSFs $\left(32 \mathrm{~g} \cdot\right.$ plot $\left.^{-1}\right)$ than in the PIs $\left(19 \mathrm{~g} \cdot\right.$ plot $\left.^{-1}\right)$ and Secar (22 $\mathrm{g} \cdot$ plot $^{-1}$; Table 3 ). An overall seed production increase was observed from 2005 to 2006 in the HSFs, PIs, and Secar. There were no major deviations in minimum and maximum temperatures or annual precipitation received between 2005 and 2006, suggesting that the year-to-year variation affecting total seed production may be explained through larger plants in year two. None of the PIs had a mean total seed yield greater than the HSF mean of $32 \mathrm{~g} \cdot$ plot $^{-1}$ (Table 1 ). A significant narrow-sense heritability estimate $\left(h^{2}\right)$ of $0.57 \pm 0.17$ was observed.

After two cycles of selection for 100-seed weight $(\mathrm{g})$, the HSFs had significantly $(P<0.05)$ heavier seeds than did the PIs and Secar (Table 3$)$. There was a significant $(P<0.01)$ entry by year interaction for 100-seed weight (Table 2) resulting from increased plant size in year two rather than a rank change between years, hence the data are combined over years. PIs 285273 and 531630 had 100 -seed weights greater than that of the HSF mean $\left(0.34 \mathrm{~g} \cdot 100\right.$ seeds $^{-1}$; Table 1$)$ and may be a source of germplasm to increase 100-seed weight in this species. A significant $b^{2}$ estimate of $0.57 \pm 0.17$ for 100 -seed weight was observed. Snake River wheatgrass HSFs had significantly $(P<0.05)$ higher rates of seedling emergence when compared

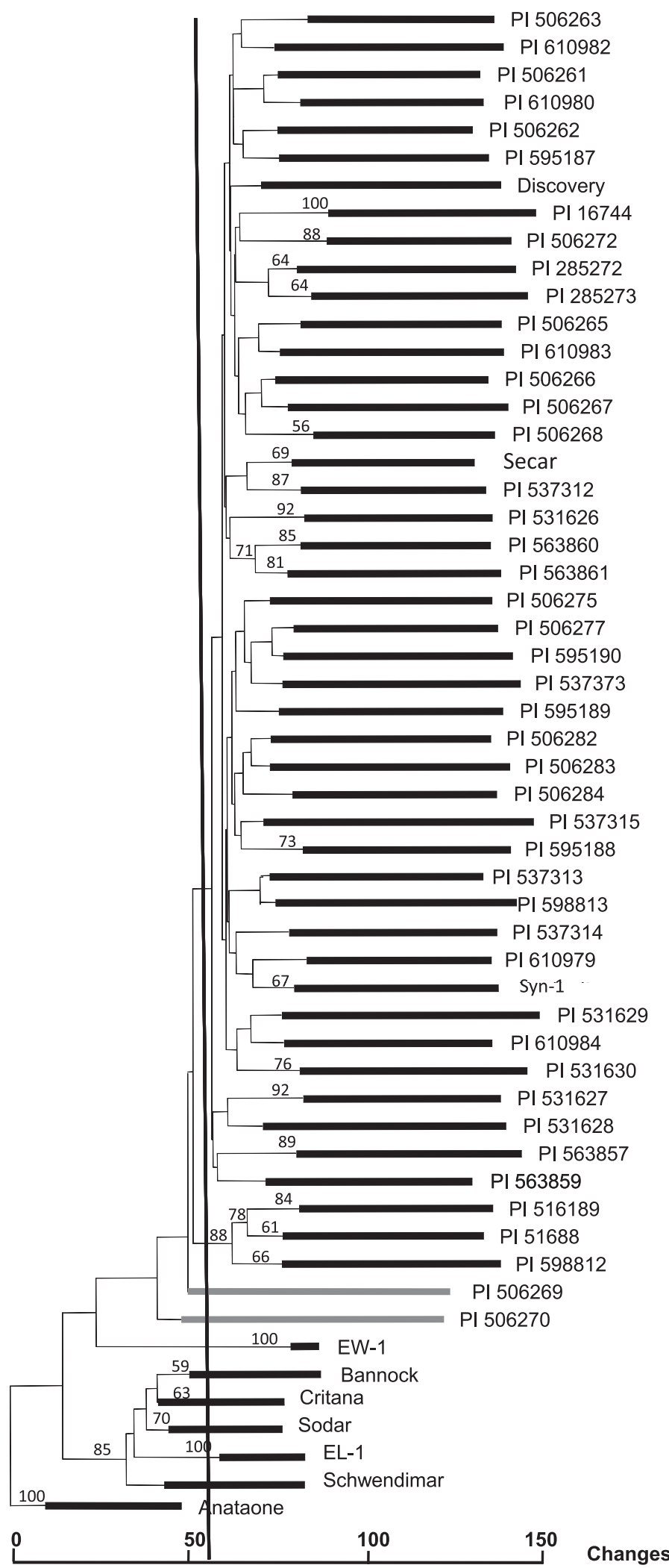

Figure 1. Neighbor-joining tree based on pairwise comparisons of total differences among 402 individual plants (amplified fragment-length polymorphism genotypes) classified and summarized by accession. The length of thick bars indicates the average proportion of shared DNA fragments per accession. Grey lines indicate not all genotypes grouped together. Bootstrap confidence levels are shown for groups in the $50 \%$ confidence tree. 
Table 2. Mean squares from analysis of variance for dry matter production, crude protein, in-vitro true digestibility, and neutral detergent fiber for 49 plant introductions of Snake River wheatgrass from the National Plant Germplasm System, 30 half-sib families of Snake River wheatgrass, and the cultivar Secar. Significance levels are indicated by * and ** $(P<0.05$ and $P<0.01$, respectively).

\begin{tabular}{|c|c|c|c|}
\hline Character & Entry & Year & Entry $\times$ year \\
\hline \multicolumn{4}{|l|}{ Seed yield $\left(g \cdot\right.$ plant $\left.^{-1}\right)$} \\
\hline 2005 & $173^{* *}$ & & \\
\hline 2006 & $802^{* *}$ & & \\
\hline 2005-2006 & $170^{\star *}$ & $66782^{\star *}$ & $243^{\star *}$ \\
\hline \multicolumn{4}{|c|}{100 -seed weight $(\mathrm{g} \cdot 100$} \\
\hline seeds $^{-1}$ ) & $0.003^{\star *}$ & & \\
\hline 2005 & $0.003^{\star *}$ & & \\
\hline 2006 & $0.005^{\star *}$ & $0.014^{\star \star}$ & $0.001^{\star *}$ \\
\hline \multicolumn{4}{|l|}{ 2005-2006 } \\
\hline \multicolumn{4}{|c|}{$\begin{array}{l}\text { Seedling emergence (seedlings } \\
\text { emerged } \cdot \text { day }^{-1} \text { ) }\end{array}$} \\
\hline 2005 & $2.05^{\star \star}$ & & \\
\hline 2006 & $1.17^{\star \star}$ & $840^{* *}$ & 0.98 \\
\hline \multicolumn{4}{|l|}{$2005-2006$} \\
\hline \multicolumn{4}{|c|}{ Dry matter yield $\left(g \cdot\right.$ plot $\left.^{-1}\right)$} \\
\hline 2005 & $12255^{\star *}$ & & \\
\hline 2006 & $20373^{\star *}$ & & \\
\hline $2005-2006$ & $29891^{* *}$ & $1202202^{\star *}$ & $2754^{\star *}$ \\
\hline \multicolumn{4}{|c|}{ Crude protein $\left(\mathrm{g} \cdot \mathrm{kg}^{-1}\right)$} \\
\hline 2005 & $522^{\star *}$ & & \\
\hline 2006 & $588^{* *}$ & & \\
\hline 2005-2006 & $826^{\star \star}$ & $5848^{* *}$ & 283 \\
\hline \multicolumn{4}{|c|}{$\begin{array}{l}\text { In vitro true digestibility } \\
\left(\mathrm{g} \cdot \mathrm{kg}^{-1}\right)\end{array}$} \\
\hline 2005 & $967^{\star *}$ & & \\
\hline 2006 & $777^{\star *}$ & & \\
\hline 2005-2006 & $1393^{* *}$ & $70258^{\star *}$ & 361 \\
\hline \multicolumn{4}{|c|}{$\begin{array}{l}\text { Digestible neutral detergent } \\
\text { fiber }\left(\mathrm{g} \cdot \mathrm{kg}^{-1}\right)\end{array}$} \\
\hline 2005 & $1015^{\star *}$ & & \\
\hline 2006 & $774^{\star *}$ & & \\
\hline 2005-2006 & 1460 ** & $15444^{\star *}$ & 326 \\
\hline \multicolumn{4}{|c|}{ Neutral detergent fiber $\left(\mathrm{g} \cdot \mathrm{kg}^{-1}\right)$} \\
\hline 2005 & $1818^{* *}$ & & \\
\hline 2006 & $1410^{* *}$ & & \\
\hline $2005-2006$ & $2653^{* *}$ & $186991^{* *}$ & $591^{* *}$ \\
\hline
\end{tabular}

to Secar, but were similar to the PIs (Table 3). An $h^{2}$ estimate of $0.18 \pm 0.25$ was observed.

\section{Forage Yield}

Mean DMY was significantly $(P<0.01)$ greater in the HSF $\left(314 \mathrm{~g} \cdot\right.$ plot $\left.^{-1}\right)$ and Secar $\left(291 \mathrm{~g} \cdot\right.$ plot $\left.^{-1}\right)$ plots than in the PIs $\left(229 \mathrm{~g} \cdot\right.$ plot $\left.^{-1}\right)$ examined. A significant entry by year interaction $(P<0.05)$ was observed for DMY, which resulted from a rank change between the HSFs and Secar; however, the rank change did not influence significance levels (Table 4). Combined over years, mean DMY in the PIs ranged from $161 \mathrm{~g} \cdot \mathrm{plot}^{-1}$ to $292 \mathrm{~g} \cdot$ plot $^{-1}$, with none of the PIs exhibiting a mean DMY greater than the $314 \mathrm{~g} \cdot \operatorname{plot}^{-1}$ (Table 1) observed in the HSF. An overall increase in mean DMY in the HSFs compared to the mean DMY in the original parental PIs 610979 (242 $\left.\mathrm{g} \cdot \mathrm{plot}^{-1}\right), 537314\left(192 \mathrm{~g} \cdot \mathrm{plot}^{-1}\right)$, and the cultivar Secar $\left(291 \mathrm{~g} \cdot\right.$ plot $\left.^{-1}\right)$ may imply the success of direct selection for DMY in HSFs of Snake River wheatgrass. Narrow-sense heritability estimates of $0.63 \pm 0.10$ in the HSFs for DMY were significant.

\section{Forage Nutritional Characteristics}

Relative differences among PIs, HSFs, and Secar for CP concentration were consistent across years as indicated by a nonsignificant entry by year interaction in the combined analysis (Table 2). Mean CP concentration was significantly $(P<0.01)$ greater in the HSFs $\left(101 \mathrm{~g} \cdot \mathrm{kg}^{-1}\right)$ than in Secar $\left(87 \mathrm{~g} \cdot \mathrm{kg}^{-1}\right)$, but similar to the PIs $\left(105 \mathrm{~g} \cdot \mathrm{kg}^{-1}\right)$; Table 4). A nonsignificant $h^{2}$ estimate $(0.11 \pm 0.25)$ indicates little opportunity to improve CP via direct selection within HSFs. However, PIs 595189, 598812, and 598813 had CP concentrations greater than $120 \mathrm{~g} \cdot \mathrm{kg}^{-1}$ and could possibly be used in a hybridization program to improve CP concentration (Table 1).

Mean IVTD values combined over years ranged from $710 \mathrm{~g} \cdot \mathrm{kg}^{-1}$ to $773 \mathrm{~g} \cdot \mathrm{kg}^{-1}$ in the PIs, $718 \mathrm{~g} \cdot \mathrm{kg}^{-1}$ to $744 \mathrm{~g} \cdot \mathrm{kg}^{-1}$ in the HSFs, and were $714 \mathrm{~g} \cdot \mathrm{kg}^{-1}$ in Secar (Table 4). Secar had significantly $(P<0.05)$ lower digestibility than did the PIs and the HSFs, which had similar IVTD values (Table 4). A moderate $h^{2}$ estimate of $0.36 \pm 0.18$ was observed.

The portion of the NDF that is digested in the animal rumen is dNDF. As dNDF concentrations increase, the quality of the forage increases. Mean dNDF values were similar in the PIs $\left(557 \mathrm{~g} \cdot \mathrm{kg}^{-1}\right)$ and HSFs $\left(560 \mathrm{~g} \cdot \mathrm{kg}^{-1}\right)$, and were significantly higher than Secar $\left(541 \mathrm{~g} \cdot \mathrm{kg}^{-1}\right.$; Table 4). A nonsignificant $b^{2}$ estimate of $0.06 \pm 0.04$ was observed.

NDF is an estimate of digestible and indigestible cell wall components after cell solubles have been removed (Fisher et al. 1995). The NDF concentration of forage is inversely related to the amount that animals are able to consume and thus forages with low NDF have higher intake rates than those with high NDF concentrations (Oba and Allen 1999). PIs had lower $(P<0.05)$ mean NDF values than the HSFs and Secar in 2005 and the combined analysis (Table 4$)$. A significant $(P<0.01)$ entry by year interaction could be attributed to a $4 \%$ increase in NDF values in 2006 rather than a rank change. There was more variation observed in the PIs than in the HSFs and Secar (Table 4). PIs 506263, 598813, and 610982 had mean NDF values less than $562 \mathrm{~g} \cdot \mathrm{kg}^{-1}$. An $h^{2}$ estimate of $0.45 \pm 0.16$ for NDF was observed.

\section{DISCUSSION}

Given the emphasis on using locally adapted native plant materials in rangeland plantings, it is critical to understand patterns of genetic diversity that exist across the geographical distribution of a species. Conversely, a major limitation to any plant improvement program is the lack of plant materials 
Table 3. Means and ranges for seed yield, 100-seed weight, and seedling rate of emergence for 49 plant introductions (PIs) of Snake River wheatgrass (SRWG) from the National Plant Germplasm System, 28 half-sib families (HSFs) of SRWG, and the cultivar Secar.

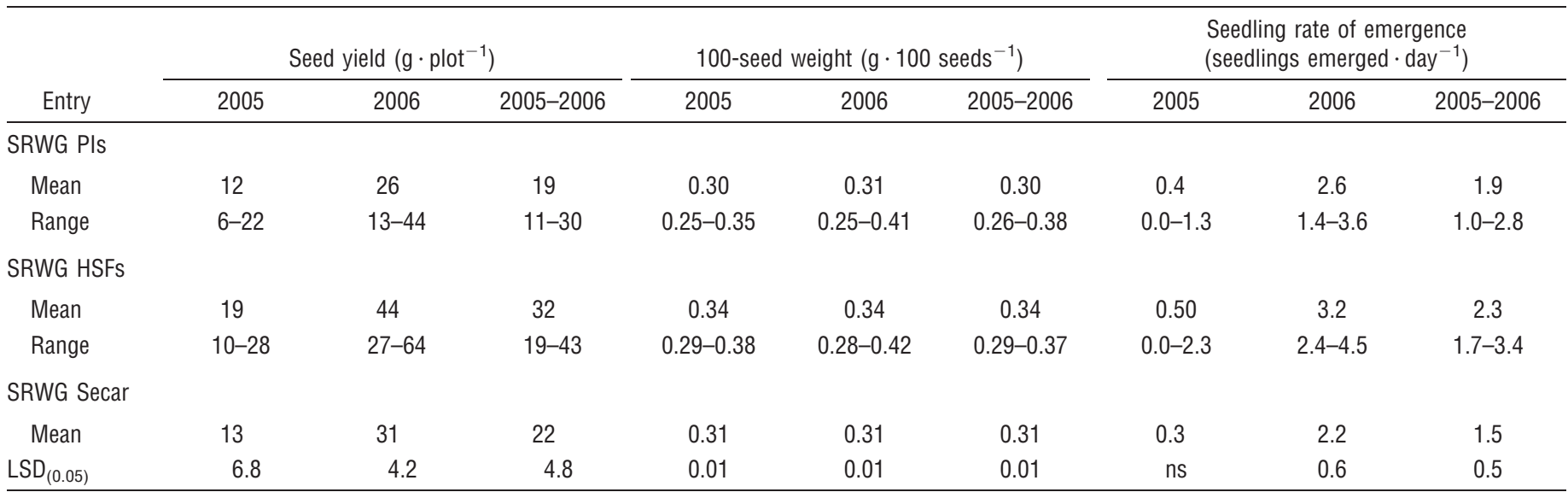

exhibiting genetic variation for traits of interest. The challenge that exists for plant development is to maintain the genetic structure within a species while improving traits that enable plant materials to establish and persist under disturbance on semiarid rangelands. The use of locally adapted plant materials and the development of improved cultivars through plant selection are often seen as opposite objectives. Results from this study suggest that within Snake River wheatgrass there is the possibility to improve Snake River wheatgrass for seed characteristics and forage traits without changing patterns of genetic diversity across Snake River wheatgrass' geographical distribution. The level of genetic differences in Secar and Syn-1 were not significantly different from the other PIs, and neither were they genetically distinct from most wild collections of Snake River wheatgrass (Fig. 1), with the exception of those collected from Enterprise, Oregon. They essentially form a common gene pool. These findings are significant given the increased emphasis placed on the need to utilize locally collected materials and the concern about improving native grasses and their effects on local populations. Within Snake River wheatgrass, it seems possible to increase, through selection, traits that will enhance Snake River wheatgrass' ability to establish on semiarid rangelands and successfully compete with invasive annuals such as cheatgrass and medusahead without affecting the overall genetic makeup of the native populations.

Poor seed production and reduced seedling establishment in many native grasses continues to hinder land managers' ability to successfully establish native grasses on harsh disturbed rangelands dominated by invasive annuals (Smith and Smith 1996; Asay et al. 2001a).

Plant selection for increased seed production in Snake River wheatgrass was successful with an increase in mean seed production in the HSF of $32.0 \mathrm{~g} \cdot$ plot $^{-1}$ compared to the mean seed production in the original HSF parental lines of PI 610979 $\left(15.3 \mathrm{~g} \cdot \mathrm{plot}^{-1}\right)$, PI537314 $\left(17.4 \mathrm{~g} \cdot \mathrm{plot}^{-1}\right)$, and the cultivar Secar (22 $\mathrm{g} \cdot$ plot $^{-1}$; Table 3). Based on the observed $h^{2}$ estimate of $0.57 \pm 0.17$, there appears to be sufficient additive genetic variation present within this HSF population to increase seed production over that of the parent populations through within and among families selection.

Selection for heavier seeds $\left(\mathrm{g} \cdot 100\right.$ seeds $\left.^{-1}\right)$ is often used as an indirect method to screen for increased seedling establishment in other important restoration species such as Russian

Table 4. Means and ranges for dry matter production, crude protein, in vitro true digestibility, digestible neutral detergent fiber, and neutral detergent fiber for 49 plant introductions (PIs) of Snake River wheatgrass (SRWG) from the National Plant Germplasm System, 28 half-sib families (HSFs) of SRWG, and the cultivar Secar.

\begin{tabular}{|c|c|c|c|c|c|c|c|c|c|c|c|c|c|c|c|}
\hline \multirow[b]{2}{*}{ Entry } & \multicolumn{3}{|c|}{$\begin{array}{l}\text { Dry matter production } \\
\left(\mathrm{g} \cdot \mathrm{plot}^{-1}\right)\end{array}$} & \multicolumn{3}{|c|}{$\begin{array}{l}\text { Crude protein } \\
\left(\mathrm{g} \cdot \mathrm{kg}^{-1}\right)\end{array}$} & \multicolumn{3}{|c|}{$\begin{array}{l}\text { In vitro true digestibility } \\
\qquad\left(\mathrm{g} \cdot \mathrm{kg}^{-1}\right)\end{array}$} & \multicolumn{3}{|c|}{$\begin{array}{l}\text { Digestible neutral detergent } \\
\text { fiber }\left(\mathrm{g} \cdot \mathrm{kg}^{-1}\right)\end{array}$} & \multicolumn{3}{|c|}{$\begin{array}{l}\text { Neutral detergent fiber } \\
\qquad\left(\mathrm{g} \cdot \mathrm{kg}^{-1}\right)\end{array}$} \\
\hline & 2005 & 2006 & $\begin{array}{l}2005- \\
2006\end{array}$ & 2005 & 2006 & $\begin{array}{l}2005- \\
2006\end{array}$ & 2005 & 2006 & $\begin{array}{c}2005- \\
2006\end{array}$ & 2005 & 2006 & $\begin{array}{c}2005- \\
2006\end{array}$ & 2005 & 2006 & $\begin{array}{l}2005- \\
2006\end{array}$ \\
\hline \multicolumn{16}{|c|}{ SRWG PIs } \\
\hline Mean & 195 & 262 & 229 & 103 & 107 & 105 & 745 & 725 & 735 & 562 & 552 & 557 & 581 & 613 & 597 \\
\hline Range & $127-261$ & $195-362$ & 161-292 & $79-124$ & $83-136$ & $85-129$ & $716-774$ & $704-772$ & $710-773$ & $526-595$ & $527-599$ & $528-597$ & $534-609$ & $566-652$ & $561-627$ \\
\hline \multicolumn{16}{|c|}{ SRWG HSFs } \\
\hline Mean & 270 & 359 & 314 & 97 & 104 & 101 & 737 & 722 & 730 & 563 & 556 & 560 & 600 & 625 & 613 \\
\hline Range & $227-318$ & $301-475$ & 273-396 & $86-113$ & $93-117$ & 90-114 & $721-755$ & $713-734$ & $718-744$ & $545-581$ & 546-568 & $545-574$ & $576-621$ & 609-639 & 594-624 \\
\hline \multicolumn{16}{|c|}{ SRWG Secar } \\
\hline Mean & 274 & 308 & 291 & 79 & 95 & 87 & 720 & 708 & 714 & 542 & 539 & 541 & 611 & 634 & 622 \\
\hline $\operatorname{LSD}_{(0.05)}$ & 29.6 & 32.2 & 26.3 & 12.3 & ns & 5.5 & 14.9 & 14.1 & 10.3 & 15.9 & 13.4 & 9.7 & 17.4 & 16.1 & 14.9 \\
\hline
\end{tabular}


wildrye (Psathyrostachys juncea [Fisch.] Nevski) and crested wheatgrass (Asay and Jensen 1996a, 1996b). Based on genetic variation for 100-seed weight and an $h^{2}$ estimate of $0.57 \pm 0.17$, selection for this trait within and among families will likely increase individual seed weight in the HSFs. Unlike Russian wildrye and crested wheatgrass where a significant correlation between 100-seed weight and seedling emergence exists, Snake River wheatgrass germplasm demonstrated a low correlation $(r=0.33 ; P<0.01)$ between these traits supporting the need for independent trait selection.

On semiarid rangelands, the more rapidly a seedling establishes the more likely it will be able to compete against invasive annuals and thus, the higher the probability of a successful rangeland planting (Johnson and Asay 1993). Recurrent selection has resulted in seedling emergence rates in the Syn-1 population ( 2.3 seedlings $\cdot$ day $\left.^{-1}\right)$ similar to that in crested wheatgrass $\left(3.2\right.$ seedlings $\left.\cdot \mathrm{day}^{-1}\right)$. The ability to further increase seedling establishment in HSFs of Snake River wheatgrass based on seedling emergence from a deep planting depth is limited as evidenced by an $b^{2}$ estimate of $0.18 \pm 0.25$. It may, however, be possible to increase seedling establishment in Snake River wheatgrass through hybridization with PIs 285273, 595189, 598813, and 610980, which exhibited seedling establishment above that of the HSF mean (Table 1). In addition, a positive correlation exists between seed production and seedling establishment $(r=0.73 ; P<0.01)$, suggesting that increased seedling establishment might be indirectly realized while selecting for increased seed production.

Even though forage yield may not be a trait critical to achieving a successful rangeland planting, it is an indication of overall plant vigor and its potential as a forage source for wildlife and livestock grazing rangelands (Asay et al. 2001a). Narrow-sense heritability estimates of $0.63 \pm 0.10$ in Snake River wheatgrass HSF for DMY, indicate that DMY can be more efficiently increased through continued within and among HSF selection rather than hybridization with PIs.

There are no reports of relative forage nutritional quality for Snake River wheatgrass in the literature. Recurrent selection within Snake River wheatgrass HSFs will not likely yield significant gains in CP concentrations given an $b^{2}$ estimate of $0.11 \pm 0.25$. PIs 595189, 598812, and 598813 had CP concentrations greater than the $120 \mathrm{~g} \cdot \mathrm{kg}^{-1}$ found in HSFs. Recurrent selection within these PIs for higher CP concentration or hybridizing them with the best HSF are two possible approaches that may result in increased CP concentrations within Snake River wheatgrass. Under rangeland conditions, Snake River wheatgrass has higher CP concentrations when compared to other range grasses such as intermediate wheatgrass (Thinopyrum intermedium [L.] Á. Löve), smooth brome (Bromus inermis Leyss.), and crested wheatgrass (Berdahl et al. 2004; Karn et al. 2006), but less than Russian wildrye (Asay et al. 2001b).

Variation for IVTD in the PIs and HSFs was similar, suggesting that increasing IVTD through hybridization would not likely increase IVTD. However, a moderate $b^{2}$ estimate of $0.36 \pm 0.18$ implies that within and among HSFs, selection may lead to increases in IVTD in this HSF population. In general, Snake River wheatgrass had higher digestibility levels (710$\left.773 \mathrm{~g} \cdot \mathrm{kg}^{-1}\right)$ and thus better forage quality than that reported under dryland conditions from June and July harvests in crested wheatgrass $\left(638 \mathrm{~g} \cdot \mathrm{kg}^{-1}\right)$, intermediate wheatgrass $\left(671 \mathrm{~g} \cdot \mathrm{kg}^{-1}\right)$, smooth brome $\left(671 \mathrm{~g} \cdot \mathrm{kg}^{-1}\right)$, and western wheatgrass $\left(688 \mathrm{~g} \cdot \mathrm{kg}^{-1}\right.$; Karn et al. 2006).

The ability to enhance forage quality by increasing dNDF in Snake River wheatgrass appears to be limited given the lack of variation in the raw collections and an $b^{2}$ estimate of $0.06 \pm 0.04$. However, based on intercharacter correlations, dNDF is strongly correlated with IVTD $(r=0.83 ; P<0.01)$ implying that selection for increased IVTD may indirectly increase dNDF in Snake River wheatgrass.

The variation for NDF values in the PIs and an $b^{2}$ estimate of $0.45 \pm 0.16$ in the HSFs suggests that either hybridization of PIs or selection within and among HSFs is likely to achieve lower NDF values (increasing forage quality). It is generally understood that as NDF decreases so does DMY. An intercharacter correlation $(r=0.66 ; P<0.01)$ between NDF and DMY in Snake River wheatgrass supports previously cited observations. However, due to negative correlations between NDF and all other forage quality traits examined, these traits are expected to decline with increased NDF.

In contrast to other range grasses, Snake River wheatgrass NDF values $\left(541-560 \mathrm{~g} \cdot \mathrm{kg}^{-1}\right)$ were lower than those of crested wheatgrass $\left(673 \mathrm{~g} \cdot \mathrm{kg}^{-1}\right)$, intermediate wheatgrass $\left(676 \mathrm{~g} \cdot \mathrm{kg}^{-1}\right)$, smooth brome $\left(644 \mathrm{~g} \cdot \mathrm{kg}^{-1}\right)$, and western wheatgrass $\left(651 \mathrm{~g} \cdot \mathrm{kg}^{-1}\right)$ when reported as whole-plant NDF values (Karn et al. 2006).

\section{IMPLICATIONS}

In rangeland restoration projects, particularly on dry, harsh, disturbed sites, it becomes a balancing act between seeding local ecotypes or improved cultivars while maintaining the genetic structure and competing against invasive annual weeds. Based on molecular genetic diversity data in Snake River wheatgrass, with the exception of collections near Enterprise, Oregon, all other collections and cultivars are not genetically different and represent a common gene pool from which to develop improved Snake River wheatgrass germplasm. Of significance is that any concerns regarding the use of improved cultivars of Snake River wheatgrass and their effect on the genetic structure in natural populations are probably not warranted. A major goal in breeding native grasses for range restoration seedings has been to increase seedling establishment to more effectively compete with invasive annual weeds. To date, recurrent selection in Snake River wheatgrass for total seed yield and seedling emergence from a deep planting depth has increased seedling establishment comparable to that of the crested wheatgrasses. However, any further improvement for seedling establishment in Snake River wheatgrass will likely result from hybridization between natural populations that exhibit increased seedling emergence, and not from direct selection. Our data suggest that sufficient genetic variation exists for DMY in Snake River wheatgrass to be increased through further selection; however, a negative correlation between DMY and improved forage quality will likely limit the ability to improve DMY along with CP and IVTD at the same time. In summary, through recurrent selection, populations of Snake River wheatgrass have been developed without 
altering their genetic structure compared to wildland collections, but with significantly increased ability to establish faster and be more competitive against invasive annuals on disturbed rangelands.

\section{LITERATURE CITED}

Asay, K. H., N. J. Chatterton, K. B. Jensen, T. A. Jones, B. L. Waldron, and W. H. HoRTon. 2003. Breeding improved grasses for semiarid rangelands. Arid Land Research and Management 17:469-478.

Asay, K. H., W. H. Horton, K. B. Jensen, and A. J. Palazzo. 2001a. Merits of native and introduced Triticeae grasses on semiarid rangelands. Canadian Journal of Plant Science 81:45-52.

Asay, K. H., and K. B. Jensen. 1996a. The wheatgrasses. In: L. E. Moser, D. R. Buxton, and M. D. Casler [EDs.]. Cool-Season Forage Grasses. Agronomy Monograph Series 34:691-724.

Asay, K. H., and K. B. Jensen. 1996b. The wildrye grasses. In: L. E. Moser, D. R. Buxton, and M. D. Casler [EDs.]. Cool-Season Forage Grasses. Agronomy Monograph Series 34:725-748.

Asay, K. H., AND D. A. Johnson. 1980. Screening for improved stand establishment in Russian wild ryegrass. Canadian Journal of Plant Science 60:1171-1177.

Asay, K. H., H. F. Mayland, P. G. Jefferson, J. D. Berdahl, J. F. Karn, and B. L. WALDRON. 2001b. Parent-progeny relationships and genotype $\times$ environment effects for factors associated with grass tetany and forage quality in Russian wildrye. Crop Science 41:1478-1484.

Barkworth, M. E., J. J. N. Campbell, and B. Salomon. 2007. Elymus L. In: M. E. Barkworth, K. M. Capels, S. Long, L. K. Anderton, and M. B. Piep [EDS.] Flora of North America. Volume 24. Magnoliophyta: Commelinidae (in part): Poaceae, part 1. New York, NY, USA: Oxford University Press.

Berdahl, J. D., J. F. Karn, and J. R. Hendrickson. 2004. Nutritive quality of coolseason grass monocultures and binary grass-alfalfa mixtures at late harvest. Agronomy Journal 96:951-955.

Bureau of Land Management. 1999. Out of ashes, an opportunity. Boise, ID, USA: Bureau of Land Management, National Office of Fire and Aviation. 28 p.

Bureau of Land Management. 2000. The Great Basin: healing the land. Washington, DC, USA: Bureau of Land Management. $36 \mathrm{p}$.

Carlson, J. R., and M. E. Barkworth. 1997. Elymus wawawaiensis: a species hitherto confused with Pseudoroegneria spicata (Triticeae, Poaceae). Phytologia 83:312-330.

Dewey, D. R. 1970. The origin of Agropyron albicans. American Journal of Botany $57: 12-18$

Fisher, D. S., J. C. Burns, And J. E. Moore. 1995. The nutritive evaluation of forage. In: R. F. Barnes, D. A. Miller, and C. J. Nelson [EDs.]. Forages. Volume 1: an introduction to grassland agriculture. Ames, IA, USA: Iowa State University Press. p. 105-115.

Goering, H. K., and P. J. Van Soest. 1970. Forage fiber analysis (apparatus, reagents, procedures, and some applications). Washington, DC, USA: USDAARS Agricultural Handbook 379. 20 p.

Hoffman, P. C., R. D. Shaver, D. K. Combs, D. J. Undersander, L. M. Bauman, and T. K. SeEger. 2001. Understanding NDF digestibility of forages. Focus on forage. Volume 3. No. 10. Madison, WI, USA: University of Wisconsin-Madison. 3 p.

Holland, J. B. 2003. Estimating and interpreting heritability for plant breeding. Plant Breeding Reviews 22:9-111.
Jensen, K. B., S. R. Larsen, B. L. Waldron, and J. G. Robins. 2009a. Increased seedling vigor in 'Hycrest II' crested wheatgrass. Journal of Plant Registrations 3:57-60.

Jensen, K. B., A. Palazzo, B. L. Waldron, J. G. Robins, B. S. Bushman, D. A. Johnson, AND D. OGLE. 2009b. Improved establishment characteristics of 'Vavilov II' Siberian wheatgrass. Journal of Plant Registrations 3:61-64.

Johnson, D. A., And K. H. Asay. 1993. Viewpoint: selection for improved drought response in cool-season grasses. Journal of Range Management 46:194-202.

Jones, A. J., AND D. C. NieLson. 1997. Defoliation tolerance of bluebunch and Snake River wheatgrasses. Agronomy Journal 89:270-275.

Jones, T. A. 2008. Notice of release of 'Discovery' Snake River wheatgrass. Native Plants Journal 9:99-102.

Jones, T. A., D. C. Nielson, and J. R. Carlson. 1991. Developing a grazing-tolerant native grass for bluebunch wheatgrass sites. Rangelands 13:147-150.

Karn, J. F., J. D. Berdahl, and A. B. Frank. 2006. Nutritive quality of four perennial grasses as affected by species, cultivar, maturity, and plant tissue. Agronomy Journal 98:1400-1409.

Littell, R. C., G. A. Milliken, W. W. Stroup, and R. D. Wolfinger. 1996. SAS ${ }^{\circledR}$ system for mixed models. Cary, NC, USA: SAS Institute, Inc. 633 p.

MaguiRE, J. D. 1962. Speed of germination-aid in selection and evaluation for seedling emergence and vigor. Crop Science 2:176-177.

Moore, K. J., L. E. Moser, K. P. Vogel, S. S. Walker, B. E. Johnson, and J. F. Pederson. 1991. Describing and quantifying growth stages of perennial forage grasses. Agronomy Journal 83:1073-1077.

Morrison, K. L., And C. A. Kelly. 1981. Secar bluebunch wheatgrass Washington State University Cooperative Extension Bulletin 0991. 6 p.

Nguyen, H. T., And D. A. Sleper. 1983. Theory and application of half-sib matings in forage grass breeding. Theoretical and Applied Genetics 64:187-196.

Norton, J. B., T. A. Monaco, J. M. Norton, D. A. Johnson, and T. A. Jones. 2004. Cheatgrass invasion alters soil morphology and organic mater dynamics in big sagebrush-steppe rangelands. In: A. L. Hild, N. L. Shaw, S. E. Meyer, D. T. Booth, and E. D. McArthur [comps]. Proceedings: weed and soil dynamics in shrubland ecosystems. Ogden, UT, USA: USDA Forest Service Rocky Mountain Research Station. p. 57-63.

OBA, M., AND M. S. Allen. 1999. Evaluation of the importance of the digestibility of neutral detergent fiber from forage: effects on dry matter intake and milk yield of dairy cows. Journal of Dairy Science 82:589-596.

SAS Institute Inc. 2006. SAS/STAT users guide. Version 9.1. Cary, NC, USA: SAS Institute Inc. 398 p.

Schneider, S., D. Roessli, and L. Excoffier. 2000. Arlequin. Version 2.0: a software for population genetic analysis. Geneva, Switzerland: Genetics and Biometry Laboratory, University of Geneva. 111 p.

Sмiтh, S. R., JR., AND S. Sмiтh. 1996. Native grass seed production manual. Arborg, MB, Canada: US Department of Agriculture, National Resources Conservation Service, University of Manitoba, and Ducks Unlimited Canada. 155 p.

Swofford, D. L. 2002. PAUP*: Phylogenetic analysis using parsimony ( ${ }^{*}$ and other methods), Version 4.0b10. Sunderland, MA, USA: Sinaur Associates. $144 \mathrm{p}$.

Vos, P., R. Hogers, M. Bleeker, M. Reijans, T. van de Lee, M. Hornes, A. Friuters, J. Pot, J. Peleman, and M. Kuiper. 1995. AFlP: a new technique for DNA fingerprinting. Nucleic Acids Research 23:4407-4414.

Young, J. A., And C. D. Clements. 2009. Cheatgrass fire and forage on the range. Reno, NV, USA: University of Nevada Press. 348 p. 